\title{
Indoor Environmental Quality in a Public Library in São Carlos, SP, Brazil
}

\author{
Guilherme C. do Nascimento, Wiclef D. Marra Júnior, Fernanda S. Peiter \\ Departamento de Hidráulica e Saneamento, Escola de Engenharia de São Carlos, Universidade de São Paulo, \\ São Carlos, Brazil \\ Email: peiterfs@gmail.com
}

Received 27 April 2016; accepted 14 July 2016; published 19 July 2016

Copyright (C) 2016 by authors and OALib.

This work is licensed under the Creative Commons Attribution International License (CC BY). http://creativecommons.org/licenses/by/4.0/

(c) $\underset{E Y}{0}$ Open Access

\begin{abstract}
The temperature, relative humidity, noise, carbon dioxide, and particulate matter $\left(\mathrm{PM}_{10}\right)$ in a public library in São Carlos, SP, Brazil, were monitored between May and September 2013. The building is naturally ventilated through tilted windows and doors. The $\mathbf{P M}_{10}$ concentrations in August and September were the highest when rainfall was at levels near zero. Over the entire study period, the temperature and relative humidity values were acceptable, but most users consider the library to be hot on hot days and cold on cold days. The $\mathrm{CO}_{2}$ and noise levels were below the recommended standard, but the users and employees of the library frequently complain about the noise levels.
\end{abstract}

\section{Keywords}

Indoor Air Quality, PM $_{10}$, Human Comfort, Noise, Public Library, Naturally Ventilated Spaces

Subject Areas: Atmospheric Sciences

\section{Introduction}

There is strong evidence that poor environmental quality compromises our health, comfort and well-being and has various destructive effects on our bodies. Whether at work, at leisure or at home, people are often exposed to pollutant levels that are well above those considered acceptable for preserving health [1]-[5]. Indoor air quality is often inadequately monitored and controlled, and its importance to health is frequently ignored.

The World Health Organization (WHO) considers indoor air pollution to be a major environmental and public health problem, especially for people in developing countries [6]. Exposure to pollutants in indoor air can cause respiratory diseases, allergies and respiratory tract irritation. Particulate matter and noise degrade the quality of the various environments that people frequent during their daily activities [7] [8].

According to Pope [9], up to the late 1990s, more than 150 studies on the effects of air pollution on health 
were published and provided strong evidence that the presence of suspended particulate matter is an important factor in cardiopulmonary diseases and increased mortality.

Noise pollution also exerts a negative influence on human health, according to the WHO. Excessive noise can cause hearing damage, interfere with communication, disturb sleep, cause cardiovascular and physiological damage, reduce intellectual performance and cause changes in social behavior. Hearing damage is often related to work environments and increased urban noise.

According to Willich et al. [10], chronic exposure to a sound intensity of approximately $60 \mathrm{dBA}$ triples the risk for a heart attack in women and increases this risk by $50 \%$ in men. Their study was conducted on 4115 survivors of heart attacks in 32 hospitals in Berlin, Germany. The limit of $85 \mathrm{dBA}$ for eight hours, which was suggested by the National Institute for Occupational Safety and Health (NIOSH) [11], is very high, and levels between 60 and $70 \mathrm{dBA}$ would be more suitable. Noise causes increased blood pressure and raises the levels of adrenaline and cortisol (stress hormones) in the blood. The authors emphasize the need to reassess the importance and proper limits of noise exposure in the workplace.

Persily and Dols [12] present measurements of air exchange rates, ventilation effectiveness and $\mathrm{CO}_{2}$ concentrations in an office/library building with mechanical ventilation in Washington, DC. The air exchange rates were approximately 0.8 air exchanges per hour, which is more than the minimum recommended by the American Society of Heating, Refrigerating and Air-Conditioning Engineers (ASHRAE) [13]. The daily peak $\mathrm{CO}_{2}$ concentrations averaged $512 \mathrm{ppm}$ on working days, which is well below the maximum of $1000 \mathrm{ppm}$ recommended by ASHRAE.

In this study, we consider the importance of IAQ in public libraries. Libraries frequently contain a large number of people sitting in place for a long time, accumulate a great deal of paper (books, magazines and newspapers), and are situated in unsatisfactory locations in the city. The $\mathrm{PM}_{10}, \mathrm{CO}_{2}$, noise, temperature and relative humidity were simultaneously measured inside and outside in São Carlos' Public Library. The goal was to verify the indoor air quality for people that use the local and the importance of the pollutants levels in their health.

\section{Methods}

\subsection{Sampling Site}

The “Amadeu Amaral” Public Library is located in downtown São Carlos, SP, Brazil $\left(22^{\circ} \mathrm{S}, 48^{\circ} \mathrm{W}\right)$, on the corner of two streets with intense vehicular and foot traffic. This location has high noise levels, which renders the library an inappropriate place for reading and studying. The library has nine employees, and approximately 100 people use the library daily. The library consists of three levels (Figure 1), which will be denoted Floor 1 (134 $\left.\mathrm{m}^{2}\right)$, Floor $2\left(128 \mathrm{~m}^{2}\right)$ and Floor $3\left(285 \mathrm{~m}^{2}\right)$. Measurements were taken on all three levels. The first floor of the building is on the ground level, and the main library collection is located on the third floor. The building is naturally ventilated through tilted windows and doors and has no ceiling fans or similar air circulation methods. During the study, the windows and doors remained open or closed, depending on the needs of the visitors. The city of São Carlos is situated in the geographical center of the state of São Paulo, in the southeastern region of Brazil. São Carlos is considered to be a medium-sized city (with 230,000 inhabitants, according to the 2010 Brazilian Census).

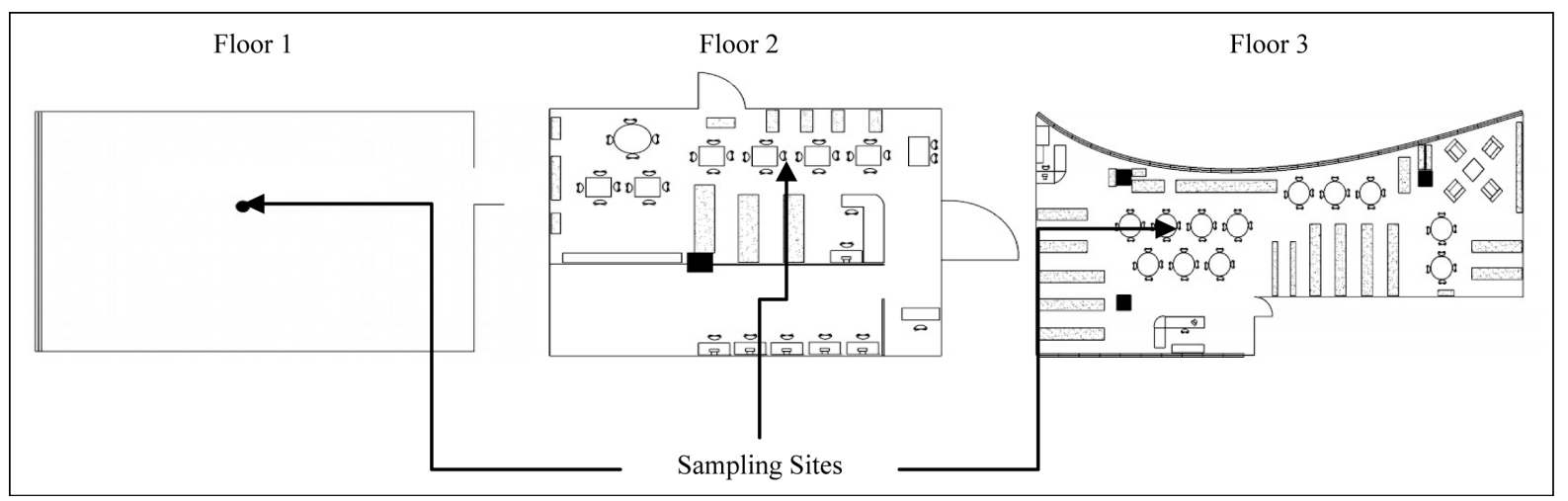

Figure 1. Sampling sites. 


\subsection{Sampling Parameters}

The temperature, relative humidity, noise, carbon dioxide level and airborne particle concentration $\left(\mathrm{PM}_{10}\right)$ were measured on each floor and outdoors. These parameters were monitored from May to September 2013. In each week of the sampling period, measurements were randomly taken on three normal workdays (08:00 to 17:00). The indoor sampling instruments were placed on supports $1.5 \mathrm{~m}$ above the ground, in the center of the room. The outdoor sampling sites were located between the library and the busiest street.

The temperature and relative humidity were measured every 15 minutes using a digital thermo hygrometer (HygroPalm-0, Rotronic Instrument Corp., New York, USA). $\mathrm{CO}_{2}$ levels were measured using a continuous multigas monitor with a range of 0 to 5000 ppm (MultiRAE IR PGM-54, Rae Systems Inc., California, USA). Noise was measured using alogging sound meter with a range of 30 to $130 \mathrm{~dB}$ (DEC-490, Instrutherm, São Paulo, Brazil). A dust monitor (Aerocet 531, Met One Instruments, Inc., Oregon, USA) was used to measure the $\mathrm{PM}_{10}$.

\section{Results and Discussion}

\subsection{Temperature and Relative Humidity}

The monthly average temperature and relative humidity values during the study period are shown in Table 1 and Table 2, respectively. A daily average was obtained using the measurements taken throughout each day, and the monthly average was defined as the arithmetic mean of the daily averages obtained during that month.

The monthly average internal and external temperatures on the three levels were not significantly different. The standard deviation of the outdoor temperature was approximately $3^{\circ} \mathrm{C}$, and the standard deviation of the indoor temperature was approximately $2^{\circ} \mathrm{C}$. These deviations show that the building has little influence on the temperature. The relative humidity inside and outside the building were also very similar, which seems to be characteristic of buildings utilizing natural ventilation.

These results enabled us to evaluate the thermal comfort of the library's visitors. Thermal comfort is defined as satisfaction with the thermal environment. The factors that influence the thermal comfort levels of the library's

Table 1. The monthly arithmetic-average temperature measurements in the library between May and September 2013.

\begin{tabular}{cccccccccc}
\hline & \multicolumn{2}{c}{ Floor 1 } & \multicolumn{2}{c}{ Floor 2 } & \multicolumn{2}{c}{ Floor 3 } & \multicolumn{2}{c}{ Floor 4 } \\
\cline { 2 - 10 } Period & $\begin{array}{c}\text { Period } \\
\text { average } \\
\left({ }^{\circ} \mathrm{C}\right)\end{array}$ & $\begin{array}{c}\text { Standard } \\
\text { deviation } \\
\left({ }^{\circ} \mathrm{C}\right)\end{array}$ & $\begin{array}{c}\text { Period } \\
\text { average } \\
\left({ }^{\circ} \mathrm{C}\right)\end{array}$ & $\begin{array}{c}\text { Standard } \\
\text { deviation } \\
\left({ }^{\circ} \mathrm{C}\right)\end{array}$ & $\begin{array}{c}\text { Period } \\
\text { average } \\
\left({ }^{\circ} \mathrm{C}\right)\end{array}$ & $\begin{array}{c}\text { Standard } \\
\text { deviation } \\
\left({ }^{\circ} \mathrm{C}\right)\end{array}$ & $\begin{array}{c}\text { Period } \\
\text { average } \\
\left({ }^{\circ} \mathrm{C}\right)\end{array}$ & $\begin{array}{c}\text { Standard } \\
\text { deviation } \\
\left({ }^{\circ} \mathrm{C}\right)\end{array}$ \\
\hline May & 22.4 & 2.6 & 22.5 & 2.9 & 22.5 & 2.7 & 21.6 & 3.8 \\
June & 21.3 & 1.8 & 21.6 & 2.1 & 21.4 & 2.0 & 21.1 & 3.1 \\
July & 23.2 & 1.4 & 23.9 & 1.5 & 23.8 & 1.5 & 23.9 & 2.8 \\
August & 23.2 & 2.7 & 23.9 & 2.9 & 23.9 & 2.8 & 24.2 & 4.0 \\
September & 25.6 & 1.9 & 26.3 & 1.8 & 26.3 & 1.8 & 26.8 & 2.2 \\
\hline
\end{tabular}

Table 2. The monthly arithmetic-average relative humidity measurements in the library between May and September 2013.

\begin{tabular}{|c|c|c|c|c|c|c|c|c|}
\hline \multirow[b]{2}{*}{ Period } & \multicolumn{2}{|c|}{ Floor 1} & \multicolumn{2}{|c|}{ Floor 2} & \multicolumn{2}{|c|}{ Floor 3} & \multicolumn{2}{|c|}{ Floor 4} \\
\hline & $\begin{array}{c}\text { Period } \\
\text { average } \\
(\%)\end{array}$ & $\begin{array}{c}\text { Standard } \\
\text { deviation } \\
\text { (\%) }\end{array}$ & $\begin{array}{c}\text { Period } \\
\text { average } \\
(\%)\end{array}$ & $\begin{array}{c}\text { Standard } \\
\text { deviation } \\
(\%)\end{array}$ & $\begin{array}{c}\text { Period } \\
\text { average } \\
(\%)\end{array}$ & $\begin{array}{c}\text { Standard } \\
\text { deviation } \\
(\%)\end{array}$ & $\begin{array}{c}\text { Period } \\
\text { average } \\
\text { (\%) }\end{array}$ & $\begin{array}{c}\text { Standard } \\
\text { deviation } \\
(\%)\end{array}$ \\
\hline May & 55.0 & 5.4 & 54.3 & 5.1 & 54.3 & 5.7 & 57.5 & 7.2 \\
\hline June & 53.7 & 7.8 & 51.8 & 8.3 & 52.5 & 7.6 & 53.5 & 12.2 \\
\hline July & 53.7 & 13.0 & 51.0 & 12.6 & 51.4 & 12.6 & 51.0 & 18.0 \\
\hline August & 39.5 & 11.5 & 37.1 & 11.6 & 37.7 & 11.5 & 36.3 & 15.4 \\
\hline September & 42.3 & 7.8 & 40.4 & 7.7 & 40.4 & 7.7 & 38.5 & 7.0 \\
\hline
\end{tabular}


occupants can be divided into environmental (temperature, thermal radiation, humidity, airspeed) and personal factors (personal activity and condition, clothing).

The literature on thermal comfort usually focuses on humidity and temperature and their influence on personal well-being. One approach to defining a comfort zone and setting appropriate limits is using the standards defined in the ISO 7730-1994 [14]. The ISO 7730 presents a method to predict the degree of discomfort in individuals exposed to moderate thermal environments and specify the environmental conditions that achieve comfort. This standard can be used to design new environments or assess existing spaces.

Figure 2 presents a combination of the daily average temperature and relative humidity over the study period for the purposes of evaluating the thermal comfort level.

Outside the comfort zone, May and June had the lowest temperatures, with daily averages of approximately $18^{\circ} \mathrm{C}$. August had the lowest average daily relative humidity (approximately 20\%) and a high average daily temperature (above $27^{\circ} \mathrm{C}$ ). Approximately $62 \%$ of the data lie within the comfort zone.

\subsection{Noise}

The monthly average noise levels are calculated in the same manner as the temperature and relative humidity averages and are shown in Table 3. The noise levels are slightly higher on the first floor than on the other two floors. A value of approximately $60 \mathrm{dBA}$ was observed inside the library, which is significantly different from the value of $68 \mathrm{dBA}$ measured outside the library. The standard deviation of the noise level was approximately 6 $\mathrm{dBA}$ outside the library and $4 \mathrm{dBA}$ inside the library. The external noise levels reached values up to $92 \mathrm{dBA}$, while the internal noise levels did not exceed $85 \mathrm{dBA}$.

According to Willich et al. [10], subjects exposed to noise levels of more than 60 decibels during the day experienced an increased risk for myocardial infarction compared to subjects with exposure to noise levels below 60 decibels. The currently employed threshold of 85 decibels may sufficiently protect the library's visitors from

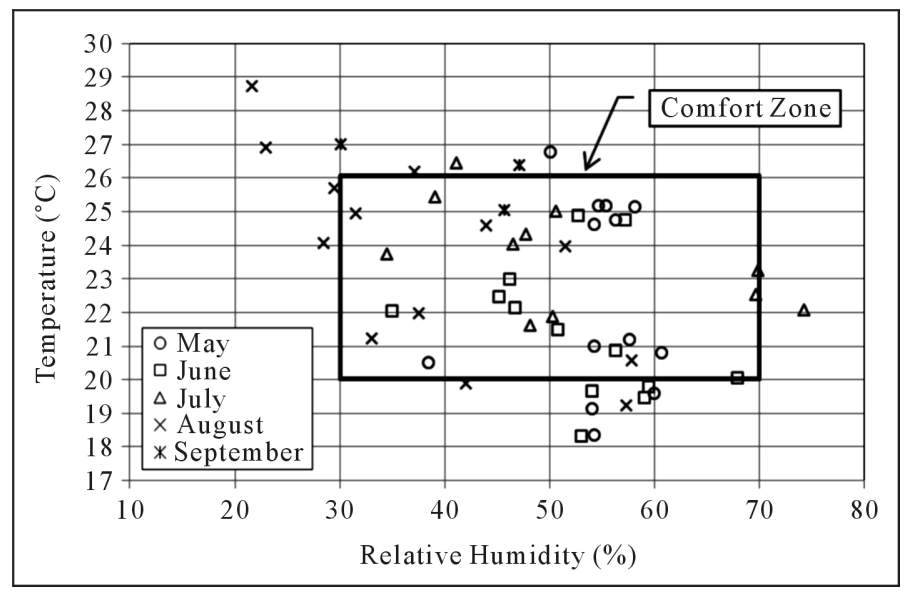

Figure 2. Results for temperature and relative humidity.

Table 3. The monthly arithmetic-average noise level measurements in the library between May and September 2013.

\begin{tabular}{|c|c|c|c|c|c|c|c|c|}
\hline \multirow[b]{2}{*}{ Period } & \multicolumn{2}{|c|}{ Floor 1} & \multicolumn{2}{|c|}{ Floor 2} & \multicolumn{2}{|c|}{ Floor 3} & \multicolumn{2}{|c|}{ Floor 4} \\
\hline & $\begin{array}{c}\text { Period } \\
\text { average } \\
\text { (dBA) }\end{array}$ & $\begin{array}{c}\text { Standard } \\
\text { deviation } \\
(\mathrm{dBA})\end{array}$ & $\begin{array}{c}\text { Period } \\
\text { average } \\
\text { (dBA) }\end{array}$ & $\begin{array}{c}\text { Standard } \\
\text { deviation } \\
(\mathrm{dBA})\end{array}$ & $\begin{array}{c}\text { Period } \\
\text { average } \\
\text { (dBA) }\end{array}$ & $\begin{array}{c}\text { Standard } \\
\text { deviation } \\
\text { (dBA) }\end{array}$ & $\begin{array}{c}\text { Period } \\
\text { average } \\
\text { (dBA) }\end{array}$ & $\begin{array}{c}\text { Standard } \\
\text { deviation } \\
\text { (dBA) }\end{array}$ \\
\hline May & 61.5 & 3.4 & 58.9 & 3.4 & 58.2 & 4.1 & 68.5 & 5.6 \\
\hline June & 60.8 & 3.7 & 59.3 & 3.8 & 58.9 & 3.8 & 68.0 & 5.7 \\
\hline July & 61.3 & 4.3 & 59.5 & 3.5 & 58.4 & 4.1 & 68.6 & 5.9 \\
\hline August & 63.0 & 4.3 & 61.0 & 3.3 & 58.1 & 3.7 & 68.1 & 6.2 \\
\hline September & 63.0 & 4.5 & 60.8 & 3.5 & 58.8 & 3.9 & 67.8 & 6.1 \\
\hline
\end{tabular}


hearing damage but not from cardiovascular risks. Noise is a frequent burden in daily life, particularly in metropolitan areas and work sites. Figure 3 shows a comparison of the average monthly noise levels with the value recommended in the cited study.

Other studies have observed the harmful effects caused by exposure to high noise levels, demonstrating the need for proper standards to preserve public health [15]-[19].

\subsection{Particulate Matter $\left(\mathrm{PM}_{10}\right)$}

The average $\mathrm{PM}_{10}$ concentrations during the study period are shown in Table 4 and Figure 4. The averages were calculated in the same manner as the other parameters. The highest outdoor $\mathrm{PM}_{10}$ averages were observed during August and September and were approximately twice as high as the averages during May, June and July. This increased $\mathrm{PM}_{10}$ concentration can partially be explained by decreased rainfall.

The indoor $\mathrm{PM}_{10}$ data exhibited similar behavior, with the highest averages in the driest months, most noticeably on the first and second floors. However, the activities performed within the environment also influence the $\mathrm{PM}_{10}$ concentration. Manipulating objects (books, magazines and newspapers), displacing people and cleaning activities can all generate and resuspend particulate matter and contribute to an increased internal $\mathrm{PM}_{10}$ concentration (i.e., the internal $\mathrm{PM}_{10}$ concentration depends on both the external environment and the internal activities).

The equipment (Hi-Vol) used by Bruno et al. [20] was located in a public square approximately $150 \mathrm{~m}$ away from the "Amadeu Amaral” Public Library. Their measured outdoor $\mathrm{PM}_{10}$ concentrations were similar to those obtained in this work. According to the authors, the $\mathrm{PM}_{10}$ concentration in the atmosphere of São Carlos varies seasonally and is higher in the dry period (from May to October) than in the rainy season (from November to April).

The WHO updated its Air Quality Guidelines in 2005 [21] based on a systematic review of the literature on the adverse health effects of air pollution. The current update is intended to be relevant and applicable worldwide and considers the large regional inequalities in air pollution exposure. It recommends guidelines for particulate matter, ozone, nitrogen dioxide and sulfur dioxide and a set of interim targets for these pollutants' concentrations to encourage a gradual improvement in air quality and a reduction in the number of health impacts. The WHO air quality guidelines for particulate matter $\left(\mathrm{PM}_{10}\right)$ concentration recommend an annual mean of 20 $\mu \mathrm{g} / \mathrm{m}^{3}$ and a 24 -hour mean of $50 \mu \mathrm{g} / \mathrm{m}^{3}$.

The monthly average particulate matter concentrations $\left(\mathrm{PM}_{10}\right)$ obtained in this study were calculated from measurements taken over 8 hours. The indoor $\mathrm{PM}_{10}$ was usually below the $50 \mu \mathrm{g} / \mathrm{m}^{3}$ value recommended by the WHO.

\subsection{Carbon Dioxide $\left(\mathrm{CO}_{2}\right)$}

The monthly average $\mathrm{CO}_{2}$ concentrations in the library are shown in Figure 5. The internal $\mathrm{CO}_{2}$ levels were slightly greater than the external values, highlighting the fact that the natural ventilation of the building renders the interior air quality similar to the exterior air quality.

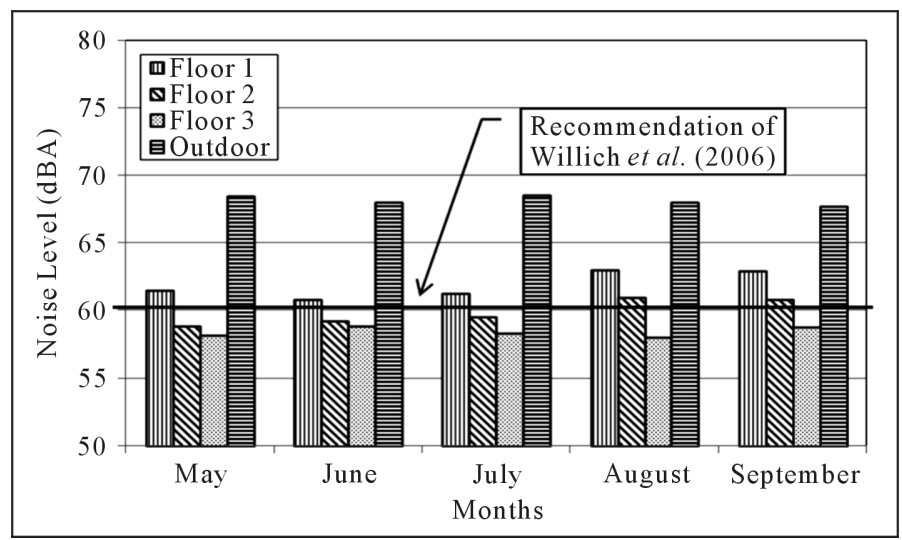

Figure 3. Results for noise. 
Table 4. The monthly arithmetic-average $\mathrm{PM}_{10}$ concentrations in the library measured between May and September 2013.

\begin{tabular}{cccccccccc}
\hline & \multicolumn{2}{c}{ Floor 1 } & \multicolumn{2}{c}{ Floor 2 } & \multicolumn{2}{c}{ Floor 3 } & \multicolumn{2}{c}{ Floor 4 } \\
\cline { 2 - 10 } Period & $\begin{array}{c}\text { Period } \\
\text { average } \\
\left(\mu \mathrm{g} / \mathrm{m}^{3}\right)\end{array}$ & $\begin{array}{c}\text { Standard } \\
\text { deviation } \\
\left(\mu \mathrm{g} / \mathrm{m}^{3}\right)\end{array}$ & $\begin{array}{c}\text { Period } \\
\text { average } \\
\left(\mu \mathrm{g} / \mathrm{m}^{3}\right)\end{array}$ & $\begin{array}{c}\text { Standard } \\
\text { deviation } \\
\left(\mu \mathrm{g} / \mathrm{m}^{3}\right)\end{array}$ & $\begin{array}{c}\text { Period } \\
\text { average } \\
\left(\mu \mathrm{g} / \mathrm{m}^{3}\right)\end{array}$ & $\begin{array}{c}\text { Standard } \\
\text { deviation } \\
\left(\mu \mathrm{g} / \mathrm{m}^{3}\right)\end{array}$ & $\begin{array}{c}\text { Period } \\
\text { average } \\
\left(\mu \mathrm{g} / \mathrm{m}^{3}\right)\end{array}$ & $\begin{array}{c}\text { Standard } \\
\text { deviation } \\
\left(\mu \mathrm{g} / \mathrm{m}^{3}\right)\end{array}$ \\
\hline May & 25.9 & 10.0 & 30.6 & 15.2 & 20.2 & 8.2 & 24.4 & 5.3 \\
June & 20.8 & 5.6 & 25.0 & 5.6 & 25.0 & 5.6 & 25.0 & 5.6 \\
July & 26.5 & 7.2 & 29.0 & 8.4 & 30.3 & 8.4 & 23.3 & 8.4 \\
August & 51.9 & 10.5 & 35.0 & 12.0 & 19.8 & 7.0 & 43.7 & 6.4 \\
September & 46.7 & 17.5 & 46.7 & 12.0 & 18.5 & 4.5 & 53.7 & 4.5 \\
\hline
\end{tabular}

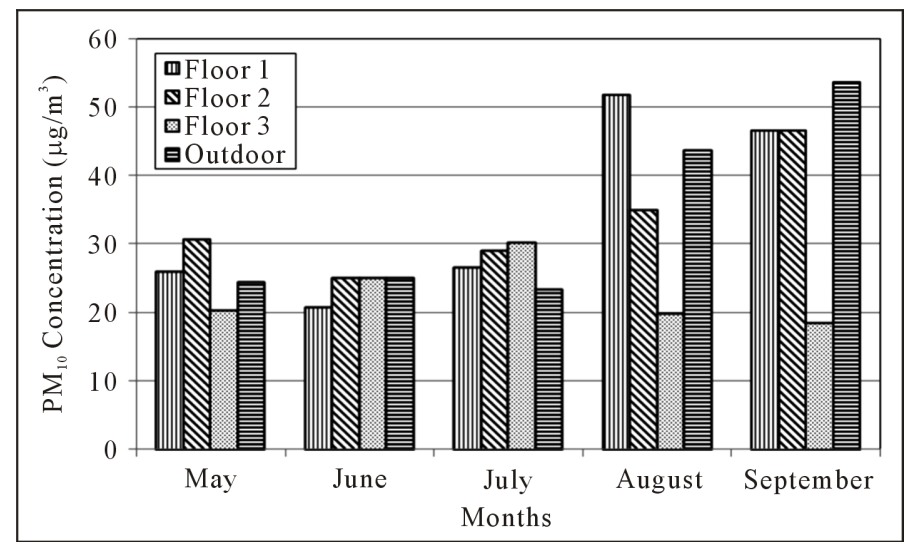

Figure 4. Results for $\mathrm{PM}_{10}$.

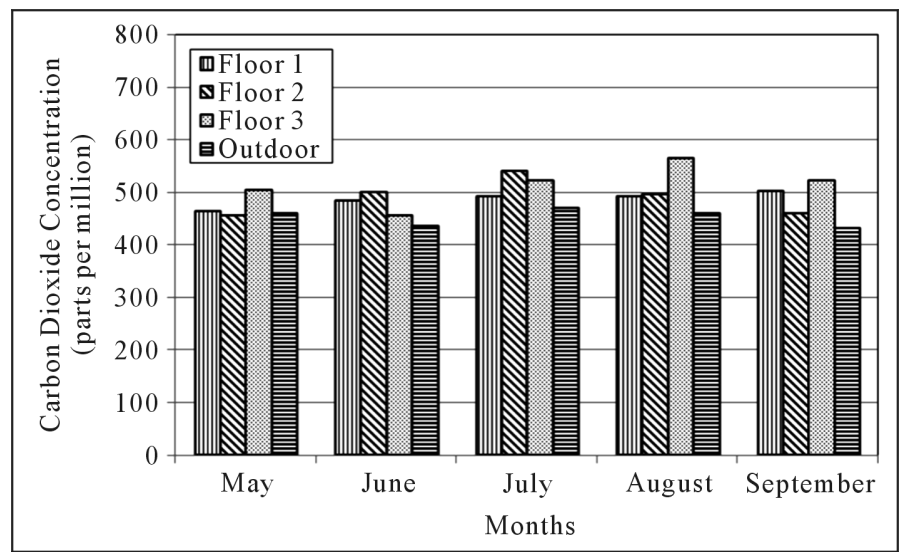

Figure 5. Results for $\mathrm{CO}_{2}$.

The mean daily peak $\mathrm{CO}_{2}$ concentration was 600 ppm, with a standard deviation of 30 ppm. ASHRAE Standard 62.1-2010 [13] recommends that $\mathrm{CO}_{2}$ concentrations be kept below 1000 ppm, and, thus, the average concentrations in the library are below the ASHRAE maximum.

In a building with constant occupancy, the daily maximum $\mathrm{CO}_{2}$ concentration is related to the building's air exchange rate. The relationship between the $\mathrm{CO}_{2}$ concentration and the air exchange rate was extensively discussed by Persily and Dols [22].

\subsection{People's Opinions Regarding the Air Quality}

To understand people's opinions regarding the air quality of the library, eighteen people (nine users and nine 
employees) were interviewed. Each interviewee was asked the following two questions: What do you think about the thermal comfort of the library? What symptoms have you experienced because of the air quality of the library?

The answers provided by respondents are summarized in Figure 6 and Figure 7. On hot days, 89\% of people think that the library is warm or hot. On cold days, $63 \%$ of people think that the library is cool or cold. The most frequently cited symptoms were sneezing, a running nose, headaches, a dry throat and dry eyes. A person could express more than one symptom. More than $55 \%$ of the respondents said they had a headache after staying in place, and more than $44 \%$ of the respondents had a runny nose and dry throat. Another common complaint from the employees is the high noise level in the library, which often disturbs communication between people and forces them to speak more loudly. Although the measured noise levels were below the recommended value of 85 $\mathrm{dBA}$ for an 8-hour workday, the staff felt uncomfortable with the overall level of noise in the library.

According to Witterseh et al. [23], the exposure to warm temperatures (around $30^{\circ} \mathrm{C}$ ) and high noise levels (more than $55 \mathrm{dBA}$ ) had negative effects on the performance of office work. The overall acceptability of working conditions was lower during exposure to either factor.

Temperature and humidity have a strong and significant impact on the perception of indoor air quality; at a constant pollution level, the perceived air quality decreases with increasing air temperature and humidity [24]. Intensity of fatigue, headache and difficulty in thinking clearly decreased when subjects worked at slightly lower levels of air temperature and humidity [25]. Poor indoor air quality can reduce the performance of office work and there is a relationship between the percentage dissatisfied with IAQ and the measured decrement in performance. Negative indoor environmental effects on performance were accompanied by negative effects on general symptoms such as headache and concentration [26].

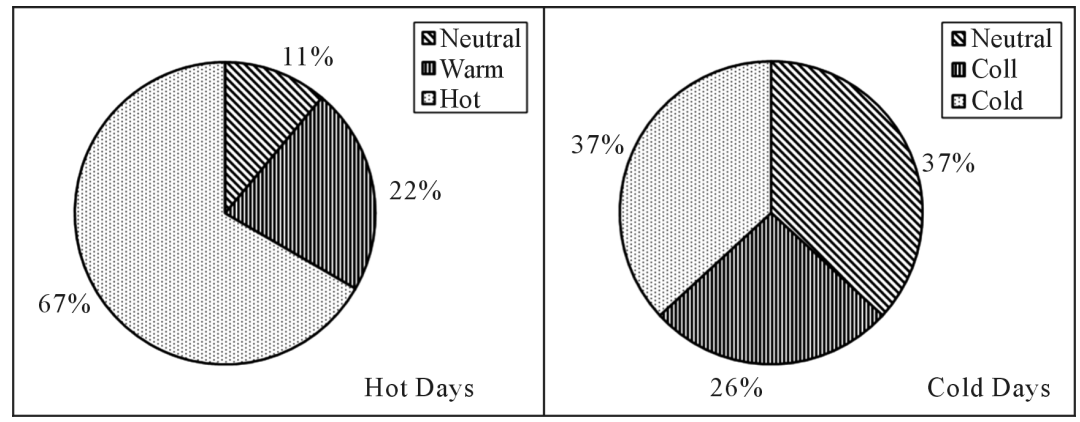

Figure 6. Results for enterview about thermal comfort.

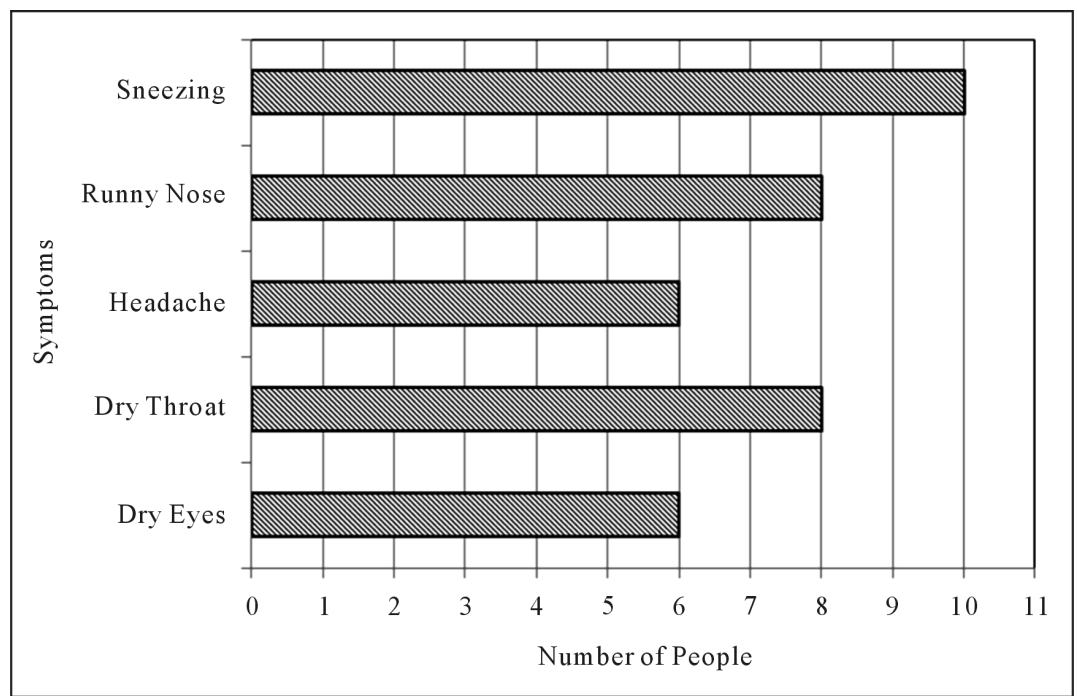

Figure 7. Results for enterview about symptoms experienced because of the air quality of the library. 


\section{Conclusions}

Over the specific period of the study, the library exhibited low indoor levels of $\mathrm{PM}_{10}$ and $\mathrm{CO}_{2}$ and acceptable ranges of temperature and humidity. In the warmer months of the year (between November and March), the site is considered to be too hot. The noise levels are below standard values but may be considered to be high for a location that people visit to read and study.

The "Amadeu Amaral" Public Library has never been located in a building designed specifically to be a library. The library has changed locations many times and has always been located in a space inappropriate for the needs of a library. Currently, the library is located in an adapted building that was originally designed to be a museum. The library is located in the downtown area, which is easy for the public to access. However, the excessive noise level caused by the vehicular traffic surrounding this location is disturbing.

Assessing the Indoor Air Quality (IAQ) of a place that many people frequent daily contributes to the understanding of the most frequent complaints of its occupants. Investigating these complaints often includes air sampling, which must be carefully conducted if representative data are to be collected. From the information obtained from these measurements, actions to improve local conditions can be taken.

According to Jones [27], we have managed our indoor environments using the best scientific advice available and our accumulating knowledge of the sources, exposures, and health impacts of indoor pollutants will need to be put to good use to ensure that the indoor environments provide the healthiest possible conditions.

\section{Acknowledgements}

The authors are grateful to FAPESP and CNPq for their support for this research. The authors especially thank the staff and administration of the "Amadeu Amaral” Public Library, who made this study possible.

\section{References}

[1] Bernstein, J.A. (2004) Health Effects of Air Pollution. Journal of Allergy and Clinical Immunology, 14, $1116-1123$. http://dx.doi.org/10.1016/j.jaci.2004.08.030

[2] Fisk, W.J. and Rosenfeld, A.H. (1997) Estimates of Improved Productivity and Health from Better Indoor Environments. Indoor Air, 7, 158-172. http://dx.doi.org/10.1111/j.1600-0668.1997.t01-1-00002.x

[3] Myers, I. and Maynard, R.L. (2005) Polluted Air-Outdoors and Indoors. Occupational Medicine, 55, 432-438. http://dx.doi.org/10.1093/occmed/kqi137

[4] Richardson, G., Eick, S. and Jones, R. (2005) How Is the Indoor Environment Related to Asthma?: Literature Review. Journal of Advanced Nursing, 53, 328-339. http://dx.doi.org/10.1111/j.1365-2648.2005.03591.x

[5] Sundell, J. (2004) On the History of Indoor Air Quality and Health. Indoor Air, 14, 51-58. http://dx.doi.org/10.1111/j.1600-0668.2004.00273.x

[6] Bruce, N., Perez-Padilla, R. and Albalak, R. (2000) Indoor Air Pollution in Developing Countries: A Major Environmental and Public Health Challenge. Bulletin of the World Health Organization, 78, 1078-1092.

[7] Frew, J.A. (2005) Advances in Environmental and Occupational Diseases 2004. Journal of Allergy and Clinical Immunology, 115, 1197-1202. http://dx.doi.org/10.1016/j.jaci.2005.03.006

[8] Pope, C.A. (1989) Respiratory Disease Associated with Community Air Pollution and a Steel Mill, Utah Valley. American Journal of Public Health, 79, 623-628. http://dx.doi.org/10.2105/AJPH.79.5.623

[9] Pope, C.A. (2000) Review: Epidemiological Basis for Particulate Air Pollution Health Standards. Aerosol Science and Technology, 32, 4-14. http://dx.doi.org/10.1080/027868200303885

[10] Willich, S.N., Wegscheider, K., Stallmann, M. and Keil, T. (2006) Noise Burden and the Risk of Myocardial Infarction. European Heart Journal, 27, 276-282. http://dx.doi.org/10.1093/eurheartj/ehi658

[11] National Institute for Occupational Safety and Health (NIOSH) (1998) Criteria for a Recommended Standard: Occupational Noise Exposure. NIOSH, Ohio.

[12] Persily, A.K. and Dols, W.S. (1991) Field Measurements of Ventilation and Ventilation Effectiveness in an Office/ Library Building. Indoor Air, 3, 229-245. http://dx.doi.org/10.1111/j.1600-0668.1991.03-13.x

[13] American Society of Heating, Refrigerating, and Air-Conditioning Engineers (2010) Ventilation for Acceptable Indoor Air Quality. Atlanta (ASHRAE Standard 62.1-2010).

[14] ISO 7730-1994 (1994) Moderate Thermal Environments: Determination of the PMV and PPD Indices and Specification of the Conditions for Thermal Comfort, International Organization for Standardization, Geneva. 
[15] Belojevic, G., Jakovljevic, B., Stojanov, V., Paunovic, K. and Ilic, J. (2008) Urban Road-Traffic Noise and Blood Pressure and Heart Rate in Preschool Children. Environment International, 34, 226-231. http://dx.doi.org/10.1016/j.envint.2007.08.003

[16] Erlandsson, S.I., Holmes, A., Widén, S.E. and Bohlin, M. (2008) Cultural and Social Perspectives on Attitudes, Noise, and Risk Behavior in Children and Young Adults. Seminars in Hearing, 29, 29-41. http://dx.doi.org/10.1055/s-2007-1021770

[17] Evans, G.W., Lercher, P., Meis, M., Ising, H. and Kofler, W.W. (2001) Community Noise Exposure and Stress in Children. The Journal of the Acoustical Society of America, 109, 1023-1027. http://dx.doi.org/10.1121/1.1340642

[18] Holgers, K.M. and Pettersson, B. (2005) Noise Exposure and Subjective Hearing Symptoms among School Children in Sweden. Noise \& Health, 7, 27-37. http://dx.doi.org/10.4103/1463-1741.31635

[19] Muzet, A. (2007) Environmental Noise, Sleep and Health. Sleep Medicine Reviews, 11, 135-142. http://dx.doi.org/10.1016/j.smrv.2006.09.001

[20] Bruno, R.L., Almeida, A.F., Nascimento Filho, V., Aguiar, M.L., Gonçalves, J.A.S. and Coury, J.R. (2004) Atmospheric Particulates Matter in the City of São Carlos/SP, Brazil. International Journal of Environment and Pollution, 22, 476-489. http://dx.doi.org/10.1504/IJEP.2004.005682

[21] WHO (2005) Air Quality Guidelines for Particulate Matter, Ozone, Nitrogen Dioxide and Sulfur Dioxide—Global Update 2005. http://www.who.int/phe/health_topics/outdoorair_aqg/en/

[22] Persily, A.K. and Dols, W.S. (1990) The Relation of Carbon Dioxide Concentration to Office Building Ventilation. In: Sherman, M.H., Ed., Air Change Rate and Airtightness in Buildings, American Society for Testing and Materials (ASTM STP1067), Philadelphia. http://dx.doi.org/10.1520/STP17206S

[23] Witterseh, T., Wyon, D.P. and Clausen, G. (2004) The Effects of Moderate Heat Stress and Open Plan Office Noise Distraction on SBS Symptoms and on the Performance of Office Work. Indoor Air, 14, 30-40. http://dx.doi.org/10.1111/j.1600-0668.2004.00305.x

[24] Fang, L., Clausen, G. and Fanger, P.O. (1998) Impact of Temperature and Humidity on the Perception of Indoor Air Quality. Indoor Air, 8, 80-90. http://dx.doi.org/10.1111/j.1600-0668.1998.t01-2-00003.x

[25] Fang, L., Wyon, D.P., Clausen, G. and Fanger, P.O. (2004) Impact of Indoor Air Temperature and Humidity in an Office on Perceived Air Quality, SBS Symptoms and Performance. Indoor Air, 14, 74-81. http://dx.doi.org/10.1111/j.1600-0668.2004.00276.x

[26] Wyon, D.P. (2004) The Effects of Indoor Air Quality on Performance and Productivity. Indoor Air, 14, 92-101. http://dx.doi.org/10.1111/j.1600-0668.2004.00278.x

[27] Jones, A.P. (1999) Indoor Air Quality and Health. Atmospheric Environment, 33, 4535-4564. http://dx.doi.org/10.1016/S1352-2310(99)00272-1

\section{Warmly welcome your paper submission to OALib Journal!}

- Publication on a daily basis

- 9 subject areas of science, technology and medicine

- Fair and rigorous peer-review system

- Fast publication process

- Article promotion in various social networking sites (LinkedIn, Facebook, Twitter, etc.)

- Widely-targeted and multidisciplinary audience to read your research

Submit Your Paper Online: Click Here to Submit

Contact Us: service@oalib.com 